\title{
Underlying social attitudes towards conservation of threatened carnivores in human-dominated landscapes
}

\author{
Francisco Zorondo-Rodríguez, Darío Moreira - Arce and Stan Boutin
}

\begin{abstract}
Carnivore conservation depends on people's willingness to implement management practices to reduce threats to carnivores and mitigate conflicts between carnivores and domestic animals. We assessed the willingness of rural communities in central-southern Chile to (1) conserve carnivores, and (2) adopt management practices to reduce predation of domestic animals, a key factor triggering carnivore-human conflicts in rural areas. The study focused on five carnivores: the chilla Lycalopex griseus, the culpeo Lycalopex culpaeus, Darwin's fox Lycalopex fulvipes, the guiña or kodkod Leopardus guigna, and the puma Puma concolor. We found that rural communities perceived that threats towards carnivores rarely occurr in their region, contrary to the literature on this subject; people's attitudes differed depending on the carnivore; and people were willing to adopt management practices to help conserve carnivores (e.g. overnight protection of domestic animals and investment in infrastructure for henhouses and cowsheds), except leashing dogs. The willingness to conserve carnivores and adopt practices that would help do so may be associated with how these measures affect people's well-being. Although rural communities would like carnivores to be conserved, this cannot be achieved unless some pivotal practices, such as management of domestic dogs, are adopted by these communities. For successful biodiversity conservation outcomes in human-dominated landscapes, the social incentives necessary for rural communities to adopt appropriate management practices must be identified and implemented.
\end{abstract}

Keywords Attitudes, carnivores, domestic animal, humanwildlife conflict, livestock, Nahuelbuta Range, predation, temperate forest

\footnotetext{
Francisco Zorondo-Rodríguez Departamento de Gestión Agraria, Facultad Tecnológica, Universidad de Santiago de Chile, Santiago de Chile, Chile

Darío Moreira-Arce* (Corresponding author) Departamento de Manejo de Bosques y Medio Ambiente, Facultad de Ciencias Forestales, Universidad de Concepción, Casilla 160-C, Victoria 631, Concepción, Chile E-mail moreira.dario@gmail.com

STAN BouTin Department of Biological Sciences, University of Alberta, Edmonton, Canada

${ }^{*}$ Also at: Department of Biological Sciences, University of Alberta, Edmonton, Alberta, Canada

Received 24 October 2017. Revision requested 16 January 2018.

Accepted 12 June 2018. First published online 25 February 2019.
}

\section{Introduction}

The attitude of people is an underlying factor in social 1 support for carnivore conservation and recovery programmes (Hågvar, 1994; Beedell \& Rehman, 2000; Romañach et al., 2007; Schumann et al., 2012). Carnivores living in anthropogenic landscapes are often persecuted and hunted by rural communities (Zimmermann et al., 2005; Romañach et al., 2007; Soto-Shoender \& Giuliano, 2011) because of predation on domestic animals and the effects of this on people's well-being (Woodroffe \& Ginsberg, 2005; Campbell \& Alvarado, 2011; Dickman et al., 2011). However, as a number of threats to carnivore survival arise from human activities (e.g. poaching, habitat conversion, management of domestic animals), the conservation of carnivores will ultimately depend on people's willingness to reduce or manage these threats. Assessing attitudes towards carnivores and the willingness of local communities to adopt practices to control threats to carnivores could increase conservation opportunities in human-dominated landscapes. This has been emphasized as a challenge by the 2010-2020 strategic plan of the Convention on Biological Diversity (CBD, 2010).

Experience and attitudes (i.e. the psychological tendency that is expressed by evaluating a particular entity with some degree of favour or disfavour; Eagly \& Chaiken, 1993) determine people's environmental behaviours (Evans \& Lepore, 1997; Knez et al., 2009). For instance, awareness of the occurrence of threats to biodiversity in a particular area, and previous experience of predation of domestic animals by carnivores could affect social support for predators in human-dominated landscapes (Evans \& Lepore, 1997). If positive attitudes towards carnivores were to increase, the adoption of carnivore-friendly management practices to reduce predation on domestic animals could become more widespread (Amador-Alcala et al., 2013), thus supporting the persistence of carnivore populations in these landscapes (Breitenmoser et al., 2005; Amador-Alcala et al., 2013; Soto-Shoender \& Main, 2013).

Many native carnivore populations exist in productionoriented lands where there is a lack of control of humanderived threats, such as invasive species, habitat modification, and retaliation for carnivore predation of livestock (e.g. Butler et al., 2004; Inskip \& Zimmermann, 2009; Vanak \& Gompper, 2009; Amador-Alcala et al., 2013; Soto-Shoender \& Main, 2013; Moreira-Arce et al., 2015). The opportunity to conserve 
carnivores in these landscapes depends on people's awareness of the main threats to carnivores described by the scientific community, and their willingness to adopt management practices to reduce carnivore predation of livestock, both of which are fundamental underlying factors for carnivore-human coexistence (e.g. Inskip \& Zimmermann, 2009; Campbell \& Alvarado, 2011; Amador-Alcala et al., 2013; Soto-Shoender \& Main, 2013; Zorondo-Rodríguez et al., 2014; Dorresteijn et al., 2016; Fernández-Gil et al., 2016; Amit \& Jacobson, 2017 b). We addressed these challenges by assessing (1) people's perception of the frequency of occurrence of threats to carnivores, and (2) people's willingness to conserve native carnivores and to adopt a set of management practices to reduce losses of domestic animals. We used data collected among rural communities of the Nahuelbuta Range, a human-dominated landscape in the coastal region of central-southern Chile.

\section{Study area}

The Nahuelbuta Range is one of the most modified ecosystems in Chile. Historically this region was covered by continuous forest comprising evergreen trees and Nothofagus species (Echeverria et al., 2006), but now the landscape is a mosaic of human-dominated lands comprising a combination of exotic tree plantations of Monterey pine Pinus radiata and Eucalyptus spp., agricultural lands, and remnants of native forest at various successional stages (Echeverria et al., 2006). Several factors, including land-use changes in the 19th century, displaced indigenous Mapuche communities towards the highlands, and new settlements comprising mainly creoles (multiracial Latin Americans) and European colonists, were established (Wolodarsky-Franke \& Díaz, 2011). Today, rural communities are characterized by scattered homes within an agricultural and forestry landscape, and include both Indigenous and non-Indigenous people. Road connectivity is poor, health services and secondary schools are scarce, and most income is derived from wood extraction and the collection of non-timber forest products (Wolodarsky-Franke \& Díaz, 2011), a common economic activity in most rural landscapes of southern Chile (Smith-Ramírez et al., 2005). Access to primary schools, electricity and drinking water is limited. These localities are recognized by the Chilean Government as territories of extreme poverty (SUBDERE, 2017). Some rural settlements in the region belong to the Indigenous Development Area Puel Nahuelbuta, which was established by the Chilean government in 2004 in recognition of ancestral uses of the territory and the close relationship between Mapuches and local biodiversity (MDS, 2004).

Despite its altered condition the Nahuelbuta Range still hosts a diverse carnivore community comprising species that are commonly perceived as predators of domestic animals in similar landscapes in southern Chile (Silva-
Rodríguez et al., 2009; Zorondo-Rodríguez et al., 2014), including the chilla Lycalopex griseus and culpeo Lycalopex culpaeus foxes, guiña Leopardus guigna and puma Puma concolor, all of which are categorized as Least Concern on the IUCN Red List, except the guiña, which is categorized as Vulnerable (IUCN, 2018). The region is also home to a small population of the Endangered Darwin's fox Lycalopex fulvipes (Moreira-Arce et al., 2015). The protected areas in the Nahuelbuta Range (e.g. Nahuelbuta National Park, 62 $\mathrm{km}^{2}$ ) do not meet the ecological requirements for maintaining viable populations of some of these species (Simonetti \& Mella, 1997; Acosta-Jamett et al., 2003), and therefore their survival depends on being able to exist in lands with numerous small villages surrounding protected areas.

\section{Methods}

During December 2013-January 2014 we conducted a semistructured questionnaire survey in three localities around Nahuelbuta National Park: Alto los Ríos, Vegas Blancas and Elicura (Fig. 1). Questionnaires were administered during local neighbourhood council meetings, which included a total of 57 residents from all localities, in 10 five-person groups and one seven-person group. In contrast with individual interviews, grouping promotes discussion, eliciting contrasting views, encouraging reflection and producing indepth explanations of the reasoning behind the responses given (Newing et al., 2011). Each group was mediated by a researcher to control for, among other issues, (1) misunderstanding of the questions, (2) any need for clarification, (3) recognition of the carnivores being considered, (4) loss of focus, (5) complacency, and (5) individual personalities. We are aware that one of the limitations of this study relates to unmeasured variables that could have influenced our findings. For example, because we captured data by group we were unable to test if attitudes differed among Indigenous and non-Indigenous individuals. Prior to the survey the questionnaire was tested on a subsample of 15 individuals to assess whether the questions were understandable. All individuals consented to participate in the survey.

We focused on the chilla, culpeo, guiña, puma and Darwin's fox, investigating four matters: (1) self-reported threats to carnivores, (2) self-reported predation on domestic animals, (3) willingness to conserve carnivores, and (4) willingness to adopt management practices for domestic animals. The questions posed were open, to elicit explanations and understanding of people's reports. The questions used to assess people's attitudes followed similarly structured questions suggested by Evans \& Lepore (1997).

Self-reported threats towards carnivores We asked 'How often do the following activities occur around the Nahuel- 


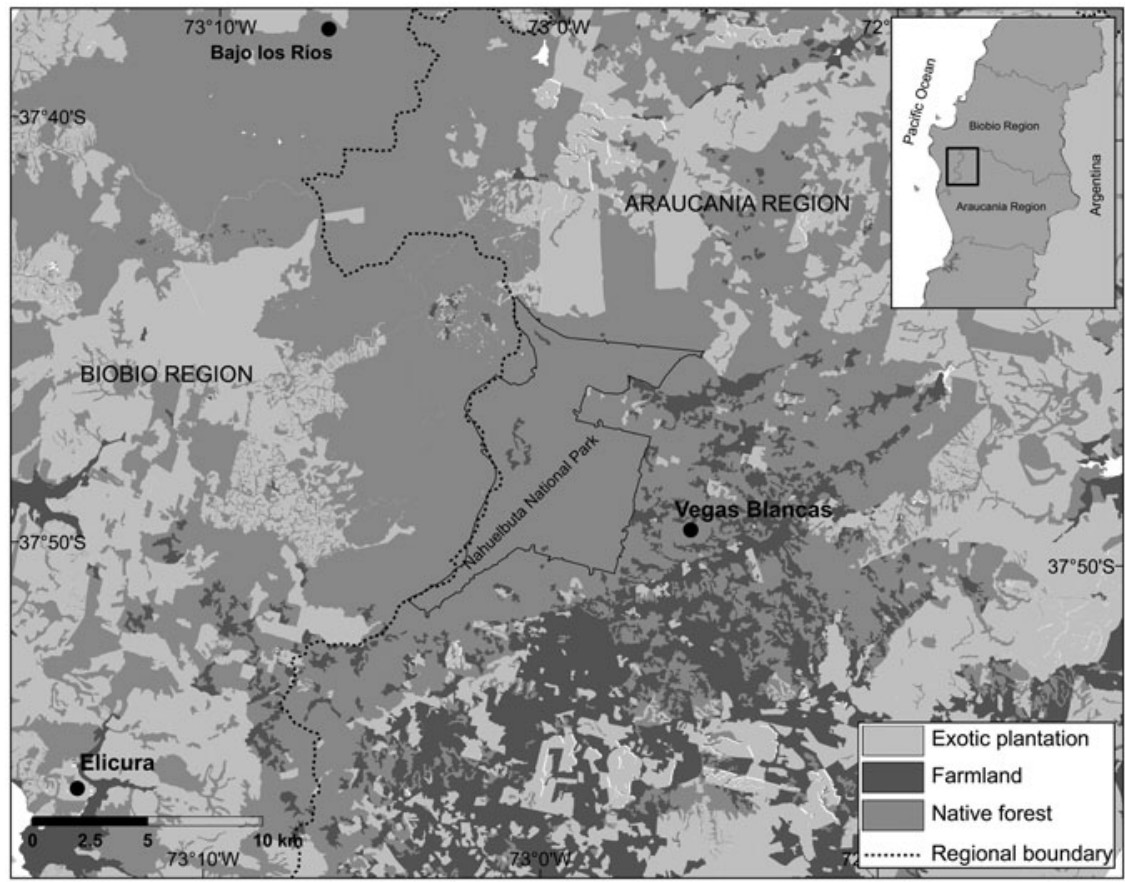

FIg. 1 Rural communities (black circles) in the Nahuelbuta Range, central-southern Chile, which were surveyed to assess people's perception of the frequency of occurrence of threats to carnivores, and their willingness to conserve native carnivores and to adopt a set of management practices to reduce losses of domestic animals. buta Range?' (a) Deforestation and replacement of native forest by exotic plantations, (b) forest fires, (c) attacks on carnivores by domestic dogs, and (d) human hunting of carnivore prey. We included forest fires as an anthropogenic threat to biodiversity because almost all forest fires in Chile are a result of human rather than natural causes (González et al., 2005). People reported the occurrence of each of the threats on a six-point Likert scale: 1, never/almost never; 2, low-medium frequency; 3 , medium frequency; 4 , medium-high frequency; 5 , high frequency; 6, always (Newing et al., 2011).

Self-reported predation of domestic animals People responded to 'How often do the following carnivores attack your domestic animals?' using the same six-point Likert scale used for threats. Using this scale we also asked people how often they used lethal control on each of the five carnivores to mitigate loss of domestic animals.

Willingness to conserve carnivores To evaluate people's willingness to conserve the five study carnivores we asked 'How much do you support the conservation of each the following carnivores?' Responses were on a six-point Likert scale: 1, strong rejection; 2, medium rejection; 3, low rejection; 4, low support; 5, medium support; 6, strong support.

Willingness to adopt management practices for domestic animals We assessed people's willingness to adopt a set of practices that could reduce predation of domestic animals and decrease the pressure on carnivore survival. We asked 'How willing are you to adopt each of the following management practices for domestic animals?' (a) overnight confinement of poultry in henhouses, (b) investment in henhouse infrastructure, (c) overnight confinement of livestock, (d) investment in cowshed infrastructure, (e) pasturage in places with low predation risk, ( $f$ ) restriction of the use of summer pasturage, ( $\mathrm{g}$ ) caring for livestock and/or poultry with guard dogs or by owners, (h) dogs being tied up on the property, and (i) dogs being free to roam the property. The differences between the last three practices are related to the specific objective of using dogs, and the type of dog management on the property. We measured their answers on a six-point scale: 1 , fully disagree; 2 , disagree; 3 , slightly disagree; 4 , slightly agree; 5 , agree; 6 , fully agree.

\section{Results}

Self-reported threats towards carnivores Participants reported that human hunting of carnivore prey occurs with moderate frequency $($ median $=2.5$; Table 1 ), and forest fires are the least frequent threat. Deforestation and replacement of native forests by exotic plantations, and attacks by domestic dogs, were reported as the most frequent threats to native carnivores (median $=3.0$; Table 1 ).

Self-reported predation of domestic animals Participants reported that the predation of domestic animals by carnivores varied between species. Attacks by culpeo and 
TABLE 1 Perceived frequency of occurrence of threats towards native carnivores in the Nahuelbuta Range in central-southern Chile (Fig. 1), according to local people interviewed during December 2013-January 2014.

\begin{tabular}{ll}
\hline Threats towards carnivores & $\begin{array}{l}\text { Median perceived frequency } \\
\text { of occurrence (range) }\end{array}$ \\
\hline $\begin{array}{l}\text { Deforestation/replacement of } \\
\text { native forest by exotic } \\
\text { plantations }\end{array}$ & $3.0(2-6)$ \\
$\begin{array}{l}\text { Forest fires } \\
\text { Hunting of carnivore prey }\end{array}$ & $1.0(1-2)$ \\
Attacks by domestic dogs & $3.0(1-6)$ \\
\hline
\end{tabular}

${ }^{1}$ Based on a six-point scale: 1, never/almost never; 2, low-medium frequency; 3 , medium frequency; 4, medium-high frequency; 5 , high frequency; 6 , always.

chilla foxes and pumas were reported to be more frequent than attacks by kodkods and Darwin's foxes (Table 2). Participants mentioned that lethal control of native carnivores is rare in the region, but culpeo foxes and pumas are sometimes killed in response to presumed predation on poultry and livestock, respectively (Table 2).

Willingness to conserve carnivores Although participants reported high willingness to promote the conservation of Darwin's fox and the kodkod (median $>5$ in both cases), there was lower support for the conservation of the culpeo and chilla foxes and the puma (Table 2).

Willingness to adopt management practices for domestic animals Participants showed high willingness to adopt management practices to reduce predation on domestic animals, including confinement (median $=6$ ), and investment in henhouses and cowshed infrastructure (median $=5.5$ and 6 , respectively). However, they were reluctant to leash domestic dogs on their properties (median $=2$ ). Most articipants preferred to keep domestic dogs free on their properties $($ median $=6$; Table 3$)$.

\section{Discussion}

Negative interactions between people and carnivores, often referred to as human-carnivore conflict, are a challenge in human-dominated landscapes (Treves \& Karanth, 2003; Inskip \& Zimmermann, 2009). We found that the social perception of carnivore conservation in the Nahuelbuta Range is of significance. Specifically, we found that (1) rural communities perceived that threats towards carnivores are moderately frequent in their region; (2) attitudes depended on the carnivore species; and (3) most participants were willing to adopt management practices that support carnivore conservation, except leashing dogs.
Conservation biologists have described the replacement of native forests by exotic plantations, the presence of domestic dogs, and hunting of carnivore prey as the main and most frequent threats to carnivores in Chile's temperate forests (Echeverria et al., 2006; Silva-Rodríguez et al., 2010; Silva-Rodríguez \& Sieving, 2011; Sepúlveda et al., 2014a; Moreira-Arce et al., 2015). In the Nahuelbuta Range, communities reported that only some of these activities are moderately frequent in this region, suggesting a gap between scientific evidence and the perceptions of threats at a local scale by rural communities. Such a gap would decrease opportunities for controlling threats if local people consider that the activities are not taking place in the area or that their occurrence is low. For example, efforts to manage free-range dogs to prevent negative interactions with native carnivores (Sepúlveda et al., 2014b; Moreira-Arce et al., 2015) would not be successful if dog owners perceived that dog attacks on carnivores and their prey were rare. If rural communities uphold a flawed perception of socio-ecological phenomena, particularly human-carnivore relationships and the need for carnivore conservation, this could lead to these communities maintaining unsustainable practices that hinder co-existence with carnivores (FernándezLlamazares et al., 2016). Our results reinforce the need to integrate local perceptions of carnivores, which are usually ignored by researchers and wildlife officers, into conservation efforts (Amit \& Jacobson, 2017a,b).

Our findings indicated that personal experiences with carnivores varied by species. Participants reported that Darwin's fox and the kodkod were not frequent predators of domestic animals, whereas culpeo and chilla foxes and pumas were the main causes of domestic animal loss. Our results also suggest that when people are directly affected by carnivores they are less willing to conserve them. However, our findings regarding social support for species conservation did not necessarily coincide with other studies. For instance, the kodkod is accepted in the Nahuelbuta Range but is persecuted by rural communities in the Maulino (Zorondo-Rodríguez et al., 2014) and temperate forests (Silva-Rodríguez et al., 2009) of central and southern Chile, respectively. In contrast, reported attitudes towards the culpeo and chilla foxes were similar to those found elsewhere in Chile, for example in the Maulino forest where there was also a moderate willingness to conserve them (Zorondo-Rodríguez et al., 2014). Variation in support for conservation of particular species in different locations may suggest that the willingness to conserve them is determined by cultural norms rather than biological and ecological traits of the species (Campbell \& Alvarado, 2011; Soto-Shoender \& Main, 2013). For example, the rural people we interviewed are of a different ethnic origin than those in studied in the Maulino and temperate forests (Silva-Rodríguez et al., 2009; Zorondo-Rodríguez et al., 2014). We therefore hypothesize that differences in attitudes towards a given carnivore species are associated with 
TABLE 2 Experience of and attitudes towards carnivores in rural communities in the Nahuelbuta Range, in central-southern Chile (Fig. 1), according to local people surveyed during December 2013-January 2014.

\begin{tabular}{llll}
\hline Carnivores & $\begin{array}{l}\text { Median self-reported predation of } \\
\text { domestic animals (range) }\end{array}$ & $\begin{array}{l}\text { Median self-reported lethal control } \\
\text { by local people (range) }\end{array}$ & $\begin{array}{l}\text { Median willingness to conserve } \\
\text { carnivores (range) }\end{array}$ \\
\hline $\begin{array}{l}\text { Darwin's fox } \\
\text { Lycalopex fulvipes }\end{array}$ & 1.0 & 1.0 & $6.0(4-6)$ \\
$\begin{array}{l}\text { Culpeo fox } \\
\text { Lycalopex culpaeus }\end{array}$ & $3.5(2-5)$ & $1.0(1-2)$ & $4.0(3-6)$ \\
$\begin{array}{l}\text { Chilla fox } \\
\text { Lycalopex griseus }\end{array}$ & $2.0(1-5)$ & 1.0 & $4.5(3-5)$ \\
$\begin{array}{l}\text { Puma } \\
\text { Puma concolor }\end{array}$ & $3.0(1-6)$ & $1.0(1-2)$ & $3.0(2-6)$ \\
$\begin{array}{l}\text { Kodkod } \\
\text { Leopardus guigna }\end{array}$ & $1.1(1-2)$ & 1.0 & $5.5(5-6)$ \\
\hline
\end{tabular}

${ }^{1}$ Based on a six-point scale: 1, never/almost never; 2, low-medium frequency; 3 , medium frequency; 4, medium-high frequency; 5 , high frequency; 6, always. ${ }^{2}$ Based on a six-point scale: 1, strong rejection; 2, medium rejection; 3, low rejection; 4, low support; 5, medium support; 6, strong support.

TABLE 3 Willingness to adopt management practices for domestic animals to reduce predation by carnivores in rural communities in the Nahuelbuta Range, central-southern Chile (Fig. 1), according to local people surveyed during December 2013-January 2014.

\begin{tabular}{ll}
\hline $\begin{array}{l}\text { Responsible practice } \\
\begin{array}{l}\text { Overnight confinement of poultry in } \\
\text { henhouses }\end{array}\end{array}$ & $\begin{array}{l}\text { Median willingness } \\
\text { to adopt (range) }\end{array}$ \\
$\begin{array}{l}\text { Investment in henhouse infrastructure } \\
\text { Overnight confinement of livestock }\end{array}$ & $5.5(3-6)$ \\
$\begin{array}{l}\text { Investment in cowshed infrastructure } \\
\text { Pasturage in places with low predation risk }\end{array}$ & $5.5(4-6)$ \\
Restriction of the use of summer pasturage & $5.0(2-6)$ \\
Taking care of livestock with guard dogs, & $3.5(1-6)$ \\
$\quad$ or by owners & \\
Dogs tied up on the property & $2.0(1-4)$ \\
Dogs free on the property & $6.0(3-6)$ \\
\hline
\end{tabular}

${ }^{1}$ Based on a six-point scale: 1 , fully disagree; 2 , disagree; 3 , slightly disagree; 4 , slightly agree; 5 , agree; 6 , fully agree.

ethnicity and communities' traditional and local management practices, which strongly influence the relationships among people, species and ecosystems (Dominguez et al., 2010; Lejano et al., 2013; Gavin et al., 2015; Guèze et al., 2015; Lopez-Maldonado \& Berkes, 2017; Reyes-García et al., 2017; Soares et al., 2017). This suggests that conservation agencies should adapt conservation strategies in accordance with the diverse relationships between rural communities and carnivores across landscapes and cultures. Although cultural and personal experiences of the loss of domestic animals shape social willingness to conserve native carnivores, self-reported experiences do not normally coincide with the frequency of attacks on domestic animals reported to public agencies (Rasmussen, 1999; Holmern et al., 2007). Thus, the low willingness to conserve particular carnivores (e.g. pumas and foxes) may be a consequence of overestimating their level of predation on domestic animals.
Such overestimation of predation and economic losses caused by native carnivores may increase negative attitudes towards carnivores and their conservation (Amit \& Jacobson, 2017b). We encourage wildlife managers to estimate real versus perceived predation of domestic animals in rural landscapes, which appears to be a determinant factor in how carnivores are perceived by local communities and therefore a pivotal element in the success of conservation actions for carnivores.

Conservation biologists have called for the adoption of management practices that decrease losses of domestic animals and reduce the persecution and killing of carnivores by local people in Chile (Silva-Rodríguez et al., 2009; Zorondo-Rodríguez et al., 2014) and elsewhere (Woodroffe et al., 2007; Inskip \& Zimmermann, 2009; Campbell \& Alvarado, 2011; Amador-Alcala et al., 2013; Soto-Shoender \& Main, 2013; Abade et al., 2014; Eklund et al., 2017; Moreira-Arce et al., 2018). We found that community members were willing to adopt all of the suggested management practices to reduce the predation of domestic animals, except the leashing of dogs. People argued that dogs are more effective if they are free-ranging because not only do they drive carnivores away (thus preventing predation of domestic animals) but they also increase the security of households. Domestic dogs are used to protect farm animals and guard houses in rural landscapes, and they are left to roam outside the properties (Vercauteren et al., 2014). Described as rural free-range dogs by Vanak \& Gompper (2009), these dogs normally remain close to houses, but also make occasional excursions into native forests and protected areas via dirt roads and trails (Sepúlveda et al., 2015). In Chilean temperate forests free-range dogs have been reported to negatively affect the habitat use of chilla foxes and southern deer Pudu puda (SilvaRodríguez et al., 2010; Silva-Rodriguez \& Sieving, 2012), preying on endemic and threatened small mammals (Silva-Rodríguez \& Sieving, 2011), and acting as reservoirs 
of pathogens of threatened carnivores (Cabello et al., 2013; Sepúlveda et al., 2014a). In the Nahuelbuta Range dogs also negatively affect the habitat use of Darwin's fox and the kodkod (Moreira-Arce et al., 2015). Our results suggest that for the long-term success of carnivore conservation in the region, efforts to implement dog management practices should consider not only the implications for carnivore ecology but also the consequences these practices would have on human well-being.

Our findings highlight the urgency of controlling freerange dogs in Chile and elsewhere, and that the low social willingness to manage dogs in rural landscapes is a major challenge for conservation efforts to protect native fauna. Although rural communities perceive the conservation of some threatened carnivores positively, the conservation actions they are willing to carry out will not yield positive outcomes unless these communities also adopt dog management practices. In rural landscapes, where dogs fulfill a socially important role and it is not possible to remove them or restrict them by night confinement or leashing, the use of complementary measures needs to be considered, such as vaccination programmes, environmental education, improved feeding strategies, or programmes for mitigation and compensation of the impacts of livestock losses for smallscale farmers (Montecino-Latorre \& San Martín, 2018). For biodiversity conservation in rural landscapes, management practices must be evaluated thoroughly, and related to human well-being, if they are to be implemented successfully.

Acknowledgements We appreciate the hospitality, kindness and friendship of the local communities in the Nahuelbuta Range, and the financial support received from the Ministry of the Environment of Chile through Fondo de Protección Ambiental (FPA NAC-I-008-2012) and Proyecto Basal USA 1555-Vridei O91775ZR PUBLIC, Universidad de Santiago de Chile. FZR was supported by Fondo Nacional de Desarrollo Científico y Tecnológico (FONDECYT) Project 11160672. DMA was supported by a Becas-Chile Comisión Nacional de Investigación Científica y Tecnológica scholarship and FONDECYT Project 3160056.

Author contributions Survey conception and design: FZR, DMA; survey administration: FZR, DMA; data analysis: FZR; contribution of analysis tools: DMA, SB; writing: DMA, SB, FZR.

\section{Conflicts of interest None.}

Ethical standards This research abided by the Oryx Code of Conduct. Free, prior and informed consent was sought before focus group discussions and interviews.

\section{References}

Abade, L., Macdonald, D.W. \& Dickman, A.J. (2014) Assessing the relative importance of landscape and husbandry factors in determining large carnivore depredation risk in Tanzania's Ruaha landscape. Biological Conservation, 180, 241-248.

Acosta-Jamett, G., Simonetti, J.A., Bustamante, R.O. \& Dunstone, N. (2003) Metapopulation approach to assess survival of Oncifelis guigna in fragmented forests of central Chile: a theoretical model. Mastozoología Neotropical, 10, 217-229.

Amador-Alcala, S., Naranjo, E.J. \& Jiménez-Ferrer, G. (2013) Wildlife predation on livestock and poultry: implications for predator conservation in the rainforest of south-east Mexico. Oryx, $47,243-250$.

Амiт, R. \& JасовSоn, S.K. (2017a) Stakeholder barriers and benefits associated with improving livestock husbandry to prevent jaguar and puma depredation. Human Dimensions of Wildlife, 22, 246-266.

Амiт, R. \& JАсовSON, S.K. (2017b) Understanding rancher coexistence with jaguars and pumas: a typology for conservation practice. Biodiversity and Conservation, 26, 1353-1374.

Beedell, J. \& Rehman, T. (2000) Using social-psychology models to understand farmers' conservation behaviour. Journal of Rural Studies, 16, 117-127.

Breitenmoser, U., Angst, C., Landry, J.M., BreitenmoserWürsten, C., Linnell, J.D.C. \& Weber, J.M. (2005) Non-lethal techniques for reducing depredation. In People and Wildlife: Conflict or Coexistence? (eds R. Woodroffe, S. Thirgood \& A. Rabinowitz), pp. 49-71. Cambridge University Press, New York, USA.

Butler, J.R.A., Du Toit, J.T. \& Bingham, J. (2004) Free-ranging domestic dogs (Canis familiaris) as predators and prey in rural Zimbabwe: threats of competition and disease to large wild carnivores. Biological Conservation, 115, 369-378.

Cabello, J., Altet, L., Napolitano, C., Sastre, N., Hidalgo, E., DÁvila, J.A. \& Millán, J. (2013) Survey of infectious agents in the endangered Darwin's fox (Lycalopex fulvipes): high prevalence and diversity of hemotrophic mycoplasmas. Veterinary Microbiology, $167,448-454$.

Campbell, M.O. \& Alvarado, M.E.T. (2011) Public perceptions of jaguars Panthera onca, pumas Puma concolor and coyotes Canis latrans in El Salvador. Area, 43, 250-256.

CBD (Convention on Biological Diversity) (2010) Strategic Plan for Biodiversity 2011-2020 and the Aichi Targets: "Living in Harmony with Nature". Https://www.cbd.int/2011-2020/ [accessed 31 October 2018].

Dickman, A.J., Macdonald, E.A. \& Macdonald, D.W. (2011) A review of financial instruments to pay for predator conservation and encourage human-carnivore coexistence. Proceedings of the National Academy of Sciences of the United States of America, 108, 13937-13944.

Dominguez, P., Zorondo-Rodríguez, F. \& Reyes-García, V. (2010) Relationships between religious beliefs and mountain pasture uses: a case study in the High Atlas Mountains of Marrakech, Morocco. Human Ecology, 38, 351-362.

Dorresteijn, I., Milcu, A.I., Leventon, J., Hanspach, J. \& FISCHER, J. (2016) Social factors mediating human-carnivore coexistence: understanding thematic strands influencing coexistence in central Romania. Ambio, 45, 490-50o.

Eagly, A.H. \& Chaiken, S. (1993) The Psychology of Attitudes. Harcourt Brace Jovanovich College Publishers, Fort Worth, USA.

Echeverria, C., Coomes, D., Salas, J., Rey-Benayas, J.M., Lara, A. \& Newton, A. (2006) Rapid deforestation and fragmentation of Chilean temperate forests. Biological Conservation, 130, 481-494.

Eklund, A., López-Bao, J.V., Tourani, M., Chapron, G. \& Frank, J. (2017) Limited evidence on the effectiveness of interventions to reduce livestock predation by large carnivores. Scientific Reports, 7 , 2097.

Evans, G.W. \& Lepore, S.J. (1997) Moderating and mediating processes in environment-behavior research. In Advances in Environment, Behavior, and Design: Toward the Integration of Theory, Methods, Research, and Utilization (eds G.T. Moore \& R.W. Marans), pp. 255-287. Plenum Press, New York, USA. 
Fernández-Gil, A., Naves, J., Ordiz, A., Quevedo, M., Revilla, E. \& Delibes, M. (2016) Conflict misleads large carnivore management and conservation: brown bears and wolves in Spain. PLOS ONE, 11, e0151541.

Fernández-Llamazares, Á., Díaz-Reviriego, I., Guèze, M., Cabeza, M., Pyhälä, A. \& Reyes-García, V. (2016) Local perceptions as a guide for the sustainable management of natural resources: empirical evidence from a small-scale society in Bolivian Amazonia. Ecology and Society, 21, 2.

Gavin, M.C., McCarter, J., Mead, A., Berkes, F., Stepp, J.R., Peterson, D. \& TAng, R.F. (2015) Defining biocultural approaches to conservation. Trends in Ecology \& Evolution, 30, 140-145.

GonzÁlez, M.E., Veblen, T.T. \& Sibold, J.S. (2005) Fire history of Araucaria-Nothofagus forests in Villarrica National Park, Chile. Journal of Biogeography, 32, 1187-1202.

Guèze, M., Luz, A.C., Paneque-Gálvez, J., Macía, M.J., Orta-Martínez, M., Pino, J. \& Reyes-García, V. (2015) Shifts in Indigenous culture relate to forest tree diversity: a case study from the Tsimane', Bolivian Amazon. Biological Conservation, 186, 251-259.

HÅgar, S. (1994) Preserving the natural heritage: the process of developing attitudes. Ambio, 23, 515-518.

Holmern, T., Nyahongo, J. \& Røskaft, E. (2007) Livestock loss caused by predators outside the Serengeti National Park, Tanzania. Biological Conservation, 135, 518-526.

Inskip, C. \& Zimmermann, A. (2009) Human-felid conflict: a review of patterns and priorities worldwide. Oryx, 43, 18-34.

IUCN (2018) The IUCN Red List of Threatened Species v. 2018-1. Http://www.iucnredlist.org [accessed 23 August 2018].

Knez, I., Thorsson, S., Eliasson, I. \& Lindberg, F. (2009) Psychological mechanisms in outdoor place and weather assessment: towards a conceptual model. International Journal of Biometeorology, 53, 101-111.

Lejano, R.P., Tavares-Reager, J. \& Berkes, F. (2013) Climate and narrative: environmental knowledge in everyday life. Environmental Science \& Policy, 31, 61-70.

Lopez-Maldonado, Y. \& Berkes, F. (2017) Restoring the environment, revitalizing the culture: cenote conservation in Yucatan, Mexico. Ecology and Society, 22, 7.

MDS (Ministerio de Desarrollo Social) (2004) Declara Area de Desarrollo Indigena a zona "Puel Nahuelbuta". DTO-168. Ministerio de Desarrollo Social (Ministerio de Planificación y Cooperación), Santiago, Chile.

Montecino-Latorre, D. \& San Martín, W. (2018) Evidence supporting that human-subsidized free-ranging dogs are the main cause of animal losses in small-scale farms in Chile. Ambio, published online 15 June 2018.

Moreira-Arce, D., Vergara, P.M. \& Boutin, S. (2015) Diurnal human activity and introduced species affect occurrence of carnivores in a human-dominated landscape. PLOS ONE, 10, e0137854.

Moreira-Arce, D., Ugarte, C.S., Zorondo-Rodríguez, F. \& Simonetti, J.A. (2018) Management tools to reduce carnivorelivestock conflicts: current gap and future challenges. Rangeland Ecology \& Management, 71, 389-394.

Newing, H., Eagle, C., Puri, R.K. \& Watson, C.W. (2011) Conducting Research in Conservation: A Social Science Perspective. Routledge, New York, USA.

RASMUSSEN, G.S.A. (1999) Livestock predation by the painted hunting $\operatorname{dog}$ Lycaon pictus in a cattle ranching region of Zimbabwe: a case study. Biological Conservation, 88, 133-139.

Reyes-García, V., Zurro, D., Caro, J. \& Madella, M. (2017) Small-scale societies and environmental transformations: coevolutionary dynamics. Ecology and Society, 22, 15.

Romañach, S.S., Lindsey, P.A. \& Woodroffe, R. (2007) Determinants of attitudes towards predators in central Kenya and suggestions for increasing tolerance in livestock dominated landscapes. Oryx, 41, 185-195.

Schumann, B., Walls, J.L. \& Harley, V. (2012) Attitudes towards carnivores: the views of emerging commercial farmers in Namibia. Oryx, 46, 604-613.

Sepúlveda, M., Pelican, K., Cross, P., Eguren, A. \& Singer, R. (2015) Fine-scale movements of rural free-ranging dogs in conservation areas in the temperate rainforest of the coastal range of southern Chile. Mammalian Biology, 80, 290-297.

Sepúlveda, M.A., Singer, R., Silva-Rodríguez, E.A., Eguren, A., Stowhas, P. \& Pelican, K. (2014a) Invasive American mink: linking pathogen risk between domestic and endangered carnivores. EcoHealth, 11, 409-419.

Sepúlveda, M.A., Singer, R.S., Silva-Rodríguez, E.A., Stowhas, P. \& Pelican, K. (2014b) Domestic dogs in rural communities around protected areas: conservation problem or conflict solution? PLOS ONE, 9, e86152.

Silva-Rodríguez, E.A., Ortega-Solís, G.R. \& Jiménez, J.E. (2010) Conservation and ecological implications of the use of space by chilla foxes and free-ranging dogs in a human-dominated landscape in southern Chile. Austral Ecology, 35, 765-777.

Silva-Rodríguez, E.A. \& Sieving, K.E. (2011) Influence of care of domestic carnivores on their predation on vertebrates. Conservation Biology, 25, 808-815.

Silva-Rodriguez, E.A. \& Sieving, K.E. (2012) Domestic dogs shape the landscape-scale distribution of a threatened forest ungulate. Biological Conservation, 150, 103-110.

Silva-Rodríguez, E.A., Soto-Gamboa, M., Ortega-Solís, G.R. \& JiMÉnEZ, J.E. (2009) Foxes, people and hens: human dimensions of a conflict in a rural area of southern Chile. Revista Chilena De Historia Natural, 82, 375-386.

Simonetti, J.A. \& Mella, J.E. (1997) Park size and the conservation of Chilean mammals. Revista Chilena De Historia Natural, 70, 213-220.

Smith-Ramírez, C., Armesto, J.J. \& Valdovinos, C. (2005) Historia, biodiversidad y ecología de los bosques costeros de Chile. Editorial Universitaria, Santiago, Chile.

Soares, D.T.N., Sfair, J.C., Reyes-García, V. \& Baldauf, C. (2017) Plant knowledge and current uses of woody flora in three cultural groups of the Brazilian semiarid region: does culture matter? Economic Botany, 71, 314-329.

Soto-Shoender, J.R. \& Giuliano, W.M. (2011) Predation on livestock by large carnivores in the tropical lowlands of Guatemala. Oryx, 45, 561-568.

Soto-Shoender, J.R. \& MAin, M.B. (2013) Differences in stakeholder perceptions of the jaguar Panthera onca and puma Puma concolor in the tropical lowlands of Guatemala. Oryx, 47, 109-112.

SUBDERE (2017) Plan de desarrollo para territorios rezagados: programa piloto y propuesta de política pública. Subsecretaría de Desarrollo Regional y Administrativo. Ministerio del Interior y Seguridad Pública, Santiago, Chile.

Treves, A. \& Karanth, K.U. (2003) Human-carnivore conflict and perspectives on carnivore management worldwide. Conservation Biology, 17, 1491-1499.

VANAK, A.T. \& Gompper, M.E. (2009) Dogs Canis familiaris as carnivores: their role and function in intraguild competition. Mammal Review, 39, 265-283.

Vercauteren, K., Lavelle, M., Landry, J.M., Marker, L. \& GeHring, T.M. (2014) Use of dogs in the mediation of conservation conflicts. In Free-Ranging Dogs and Wildlife Conservation (ed. M. Gompper), pp. 211-233. Oxford University Press, Oxford, UK.

Wolodarsky-Franke, A. \& Díz, S. (2011) Cordillera de Nahuelbuta: Reserva Mundial de Biodiversidad. WWF, Valdivia, Chile.

Woodroffe, R. \& Ginsber G, J.R. (2005) King of the beasts? Evidence for guild redundancy among large mammalian carnivores. In Large 
Carnivores and the Conservation of Biodiversity (eds J. Ray, K. Redford, R. Steneck \& J. Berger), pp. 154-158. Island Press, Washington, DC, USA.

Woodroffe, R., Frank, L.G., Lindsey, P.A., Ranah, S.M.K.O. \& Romañach, S. (2007) Livestock husbandry as a tool for carnivore conservation in Africa's community rangelands: a case-control study. Biodiversity and Conservation, 16, 1245-126o.
Zimmermann, A., Walpole, M.J. \& Leader-Williams, N. (2005) Cattle ranchers' attitudes to conflicts with jaguar Panthera onca in the Pantanal of Brazil. Oryx, 39, 406-412.

Zorondo-Rodríguez, F., Reyes-García, V. \& Simonetti, J.A. (2014) Conservation of biodiversity in private lands: are Chilean landowners willing to keep threatened species in their lands? Revista Chilena De Historia Natural, 87, 4. 